\title{
Silicon carbide hollow fiber membranes developed for the textile industry wastewater treatment
}

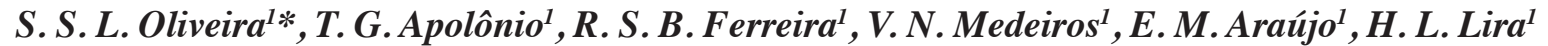 \\ ${ }^{I}$ Federal University of Campina Grande, Membranes Development Laboratory, Campina Grande, PB, Brazil
}

\begin{abstract}
In order to reduce the impacts of the industrial effluent on the environment, silicon carbide hollow fiber membranes were prepared by the precipitation-immersion technique and sintered at 1450 and $1500{ }^{\circ} \mathrm{C}$. The membranes were characterized by X-ray diffraction, their surface structure was characterized by scanning electron microscopy and atomic force microscopy, pore size distribution and porosity, mechanical properties, and flow measurements with distilled water and effluent generated by the indigo blue industry. The sintered membranes presented crystalline phases of silicon carbide and aluminum oxide. The tubes presented defect-free microstructure and uniform porous surface, with porosity above $50 \%$. The silicon carbide membrane presented significant reductions of the solutes and colloidal particle contents in the effluent. The membranes sintered at $1500{ }^{\circ} \mathrm{C}$ proved to be more efficient for reductions of the turbidity and color of the effluent. Silicon carbide hollow fiber membrane is an interesting alternative for the treatment of effluents from the textile industry.
\end{abstract}

Keywords: ceramic membranes, hollow fiber, silicon carbide, indigo blue.

\section{INTRODUCTION}

Membranes are defined as selective barriers capable of controlling the permeation rate of a particular chemical species present in a solution, providing its total or partial purification [1, 2]. The geometric configuration delimits the performance of membrane separation processes. Membranes with flat or tubular configuration have low permeate flows, as well as limitations in terms of low surface area per volume unit when compared to hollow fiber membranes [3, 4]. Hollow fiber membranes have diameters of $\sim 1-2 \mathrm{~mm}$, which makes them more favorable due to their high membrane area per unit of volume. To prepare hollow fiber membranes, phase inversion is the most used method, and the final morphology is dependent on the interactions between the processing variables: flow rate of the internal liquid and dope solution, dimensions of the extruder, air gap, stresses during the flow inside the extruder, and type of the internal liquid [5-7].

Hollow fiber membranes made of ceramic have some advantages: chemical stability, resistance to high temperatures and pressures, can be used in chemically aggressive environments in the presence of organic solvents, acids, and bases [8-11], and allow more efficient membrane cleaning processes facilitating reuse [12], in addition to considerable biological stability [13]. Among ceramic materials, silicon carbide $(\mathrm{SiC})$ stands out as a promising material for preparing inorganic membranes due to its properties: excellent mechanical resistance at high temperatures, good resistance to oxidation and thermal

*sandriely_sonaly@hotmail.com

Dhttps://orcid.org/0000-0002-7430-0597 shock, and low density $[14,15]$. The sintering of pure SiC needs to be carried out at high temperatures of $\sim 2000{ }^{\circ} \mathrm{C}$ [16] and according to Gubernat et al. [17], this process involves high energy consumption and limits large-scale production for industrial use. This problem can be solved with the use of additives to decrease the sintering temperature of $\mathrm{SiC}$, such as $\mathrm{Al}_{2} \mathrm{O}_{3}$ [18] and $\mathrm{Y}_{2} \mathrm{O}_{3}$ [19], to prepare porous $\mathrm{SiC}$ with high porosity and flexural strength at $1450{ }^{\circ} \mathrm{C}$. The addition of sintering additives (such as $\mathrm{Al}_{2} \mathrm{O}_{3}$ and $\mathrm{Y}_{2} \mathrm{O}_{3}$ ) can be performed due to the low-cost of these materials when compared to $\mathrm{SiC}$.

Water treatment is a crucial field closely related to environmental, economic, and social issues. One of the main problems of industries is the treatment of effluent before being discharged into the environment or in a public sewer system [20-22]. Inadequate disposal of these effluents affects air, water, soil, and quality of life in general. Membrane technology shows itself as an alternative to minimizing these environmental impacts, since they have affordable cost, low energy expenditure, and high efficiency, compared to conventional processes [23-26]. Silicon carbide membranes are present in several separation processes and, at the same time, have high selectivity and permeability due to their excellent properties. De Wit et al. [27] evaluated the mechanical robustness and permeability of silicon carbide hollow fibre membranes, analyzing the influence of heat treatment on the structure and properties of the prepared fibres. Dilaver et al. [28] investigated the filtration efficiency of silicon carbide membranes with two types of substrates for water/vegetable oil separation. The literature on the application of the membranes of silicon carbide to the separation process of textile effluents is still scarce, so the main objective of this work was to evaluate the behavior of the separation process of an indigo blue solution by silicon 
carbide hollow fiber membranes obtained by the method of precipitation-immersion, with alumina as an additive, and applying a low sintering temperature.

\section{MATERIALS AND METHODS}

Materials: it was used a silicon carbide powder $(\alpha-\mathrm{SiC}$, Treibacher Schleifmittel), with an average particle size of $4.0 \mu \mathrm{m}$ and $95 \%$ purity $\left(2.49 \% \mathrm{SiO}_{2}, 0.50 \% \mathrm{Fe}, 0.39 \% \mathrm{Al}\right.$, $\left.0.71 \% \mathrm{Fe}_{2} \mathrm{O}_{3}, 0.74 \% \mathrm{Al}_{2} \mathrm{O}_{3}\right)$, calcinated alumina $\left(\alpha-\mathrm{Al}_{2} \mathrm{O}_{3}\right.$, Treibacher Schleifmittel) with an average particle size of 5.0 $\mu \mathrm{m}$, polyvinylpyrrolidone (PVP,Labsynth), polyethersulfone (PES, Solvay) solvent polymer, and 1-methyl-2-pyrrolidone (NMP, Neon Com.) with $99.92 \%$ purity.

Methods: the dope solution was prepared from the dissolution of the PES with NMP solvent under mechanical stirring for $1 \mathrm{~h}$ at a speed of $1000 \mathrm{rpm}$. It was then added to the solution $\mathrm{SiC}, \mathrm{Al}_{2} \mathrm{O}_{3}$ and PVP. The resulting mixture containing $47.5 \mathrm{wt} \%$ of $\mathrm{SiC}, 2.5 \mathrm{wt} \%$ of $\mathrm{Al}_{2} \mathrm{O}_{3}, 2.5 \mathrm{wt} \%$ of PVP, $10 \mathrm{wt} \%$ of PES, and $37.5 \mathrm{wt} \%$ of NMP was stirred by 30 $\mathrm{min}$ at a speed of $300 \mathrm{rpm}$. Alumina was used as a sintering agent in order to reduce the maximum sintering temperature [29-31]. The hollow fiber membranes were extruded in wire form through the technique of precipitation-immersion (Fig. 1). The processing conditions are shown in Table I. The flow of the internal liquid (distilled water) was kept fixed at 350 $\mathrm{mL} / \mathrm{h}$ with the aid of a syringe pump (SP900Vet, Centaurus Medical). For the bath of precipitation, distilled water was used and the process was made at room temperature in air.

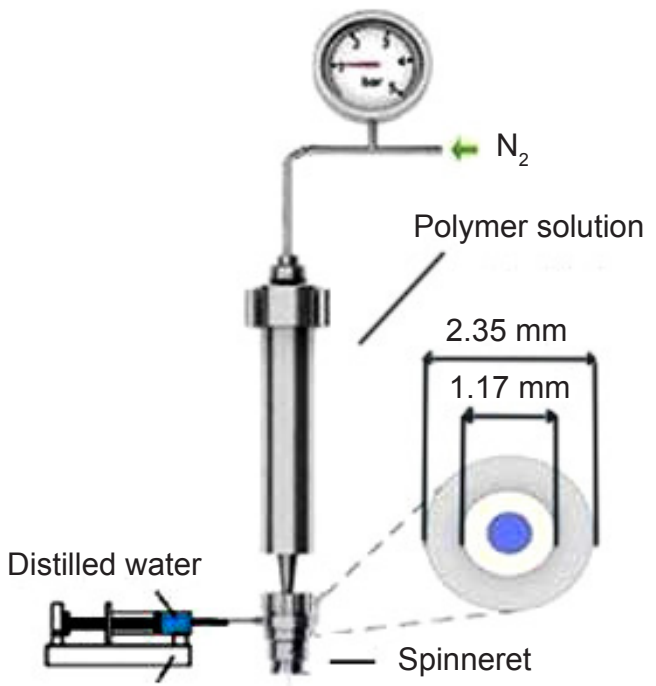

\section{Syringe pump}

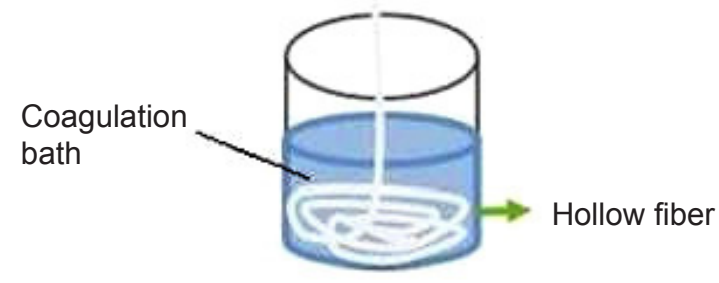

Figure 1: Schematic representation of the laboratory system used to prepare the $\mathrm{SiC}$ hollow fiber membranes.
Table I - Parameters used for preparing hollow fiber membranes.

\begin{tabular}{cc}
\hline Parameter & Value \\
\hline Internal liquid & $\mathrm{H}_{2} \mathrm{O}$ \\
Precipitation bath & $\mathrm{H}_{2} \mathrm{O}$ \\
Pressure & $500 \mathrm{kPa}$ \\
Air gap & $10 \mathrm{~cm}$ \\
Bore fluid flow rate & $350 \mathrm{~mL} / \mathrm{h}$ \\
External extruder diameter $(\mathrm{mm})$ & $2.35 \mathrm{~mm}$ \\
Internal extruder diameter $(\mathrm{mm})$ & $1.17 \mathrm{~mm}$ \\
\hline
\end{tabular}

The distance between the extruder outlet and the coagulation bath (air gap) was $10 \mathrm{~cm}$. After processing, the fibers were immersed in water for $24 \mathrm{~h}$ for solvent output. Then, the hollow fibers were dried at room temperature and sintered at 1450 and $1500{ }^{\circ} \mathrm{C}$, with a heating rate of $2{ }^{\circ} \mathrm{C} / \mathrm{min}$ up to $500{ }^{\circ} \mathrm{C}$ and $5{ }^{\circ} \mathrm{C} / \mathrm{min}$ up to the final temperature, without controlled atmosphere, in a conventional electric oven (Maitec Fornos Inti). After the heat treatment, the fibers were cut to the length of $5 \mathrm{~cm}$, for the assembly of the modules.

Characterizations: the membranes were characterized by X-ray diffraction (XRD) using a diffractometer (XRD6000 , Shimadzu) with $\mathrm{CuK} \alpha$ radiation $(\lambda=1.5418 \AA)$ at 40 $\mathrm{kV}, 30 \mathrm{~mA}$, scan from $5^{\circ}$ to $80^{\circ}$, and scanning rate of $2^{\circ} / \mathrm{min}$. For the morphological characterization of the membranes, a scanning electron microscope (SEM, Superscan SSX 550 , Shimadzu) operating at $15 \mathrm{kV}$ was used. The surface topography and the relative surface roughness of the prepared membranes were examined using an atomic force microscope (AFM, mod. 9700, Shimadzu), using the dynamic mode at a scan rate of $1 \mathrm{~Hz}$. The membranes were fixed on a support, scanned in a $15 \times 15 \mu \mathrm{m}$ area, and analyzed with the SPM Manager program. The topographic images were used to calculate the area roughness average (Ra) of the membrane by:

$$
\mathrm{Ra}=\frac{1}{\mathrm{~L}_{\mathrm{x}} \mathrm{L}_{\mathrm{y}}} \int_{0}^{\mathrm{L}_{\mathrm{y}}} \int_{0}^{\mathrm{L}_{\mathrm{x}}}|\mathrm{f}(\mathrm{x}, \mathrm{y})| \mathrm{dx} \cdot \mathrm{dy}
$$

The porosity and pore size of the membranes was obtained by mercury porosimetry (Autopore IV, Micromeritics). A test machine (Emic) was used to determine the tensile strength of the membranes, which was determined using a three-point bending apparatus with a load cell of $5 \mathrm{kN}$ at a crosshead speed of $0.5 \mathrm{~mm} / \mathrm{min}$ until fracture. The bending strength was calculated by:

$$
\sigma_{\mathrm{F}}=\frac{8 \mathrm{~F} \cdot \mathrm{LDo}}{\pi\left(\mathrm{Do}^{4}-\mathrm{Di}^{4}\right)}
$$

where $\mathrm{F}$ is the force at which the fracture of specimen took place, $\mathrm{L}$ is the span $(40 \mathrm{~mm})$, and Do and Di are the outer and inner diameters of the hollow fiber, respectively; for each sample, ten specimens were tested. For the flow measurement test with distilled water, a bench system with 


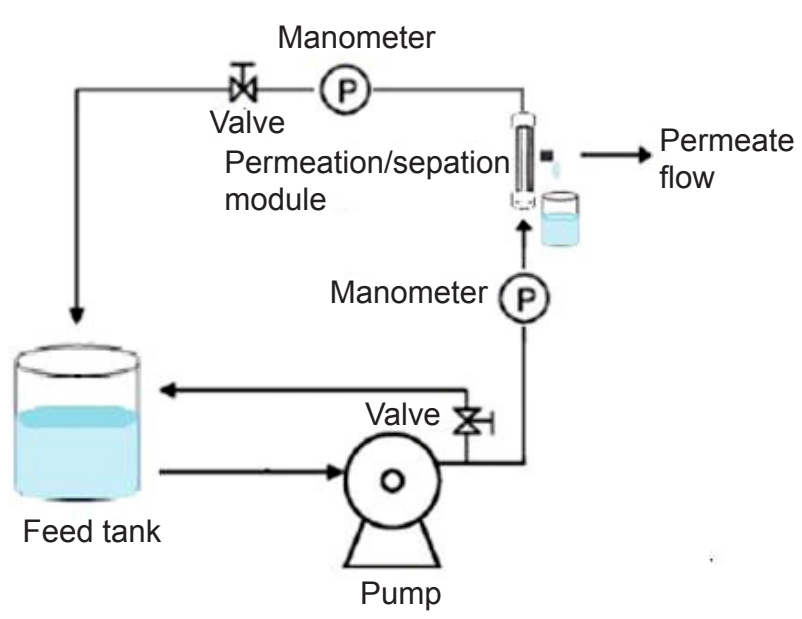

Figure 2: Schematic representation of the system used for permeated flow measurements.

a tangential flow at pressures of 100 and $200 \mathrm{kPa}$ and room temperature $\left(25^{\circ} \mathrm{C}\right)$ was used. In the system to collect the permeate flow, a reservoir for the effluent, a centrifugal pump, a module, two valves, and two manometers were used to measure the pressure of the effluent flow in the system (Fig. 2). The volumetric flow (J) collected for all membranes was calculated by:

$$
\mathrm{J}=\frac{\text { Permeated volume }(\mathrm{L})}{\text { Membrane area }\left(\mathrm{m}^{2}\right) \times \text { Time }(\mathrm{h})}
$$

The same system was used for the tests with the textile effluent. The indigo blue solution was prepared at the concentration of $10000 \mathrm{ppm}$. The test of turbidity was performed on a portable turbidimeter (Hanna) and the color test with a colorimeter (Policontrol).

\section{RESULTS AND DISCUSSION}

Fig. 3 presents the mineralogical phases identified by $\mathrm{X}$-ray diffraction of the membranes after sintering at 1500 and $1450{ }^{\circ} \mathrm{C}$. The peaks referring to $\alpha$-silicon carbide phase $\left(34^{\circ}, 36^{\circ}, 38^{\circ}\right.$ and $\left.42^{\circ}\right)$ identified by the JCPDS $73-$ 1663 file $[32,33]$, cristobalite phase of silicon oxide $\left(22^{\circ}\right.$, $28^{\circ}$ and $31^{\circ}$ ) identified by the JCPDS 39-1425 file, and $\alpha$-alumina phase $\left(35^{\circ}\right.$ and $\left.43^{\circ}\right)$ identified by the JCPDS 77-1123 file were observed. These crystalline phases were also observed in other studies [25, 27, 34]. It is possible to observe that with the increase in sintering temperature, an amount of cristobalite was formed, due to the reaction of $\mathrm{SiC}$ with oxygen in the air. The cristobalite has a structural arrangement of $\alpha$ phase at low temperature and $\beta$ phase at high temperature, above $1470{ }^{\circ} \mathrm{C}[35]$.

Fig. 4a illustrates the microstructure of the cross-section of the sintered hollow fiber membrane sintered at $1450{ }^{\circ} \mathrm{C}$. It was possible to observe an asymmetric structure that consisted of a spongy region with voids similar to 'fingers', which is a typical structure for the hollow fibers prepared by the spinning method and were generated due to the rapid exchange between solvents (NMP) and not solvents [36,

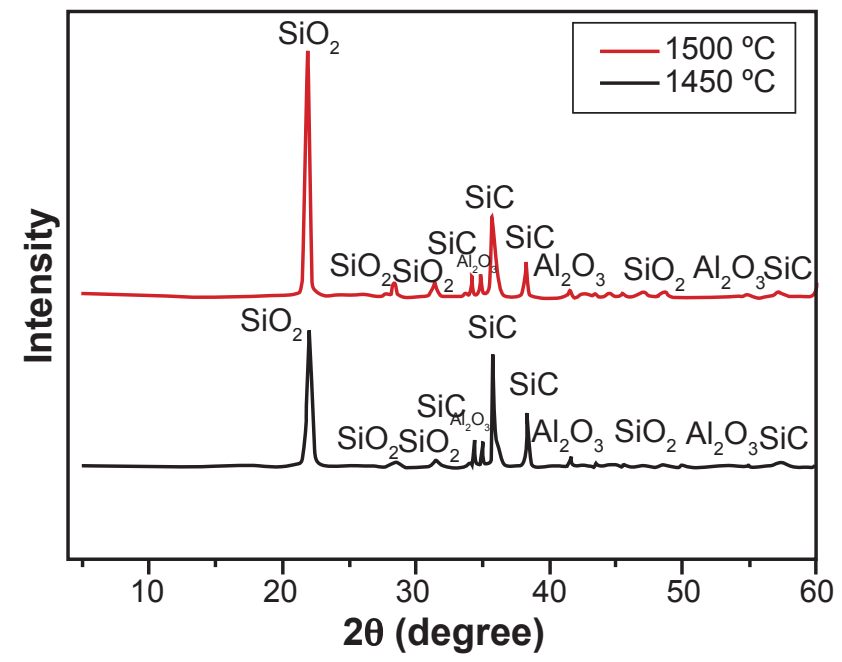

Figure 3: X-ray diffraction patterns of sintered membranes at 1450 and $1500{ }^{\circ} \mathrm{C}$.

37]. The finger-like structure originating from the interior to half of the cross-section provided high porosity to the membrane. Besides that, the porosity was associated with the output of the polymer during the sintering process. In Fig. $4 b$, it is noted the presence of sharp and irregular grains, characteristic of $\alpha$-silicon carbide phase, as identified by the X-ray diffraction. According to Nikkam et al. [33], the morphology of $\alpha$-SiC grain may be dominated by the anisotropic crystal structure, allowing the crystal to grow in certain directions more than the other directions. In Fig. $4 \mathrm{c}$, more evidences of irregular and asymmetric shape of the membrane pores are shown. Finally, in Fig. 4d, the cross-sectional image focusing on the surface near the inner part shows that the hollow fiber membrane was porous throughout its section.

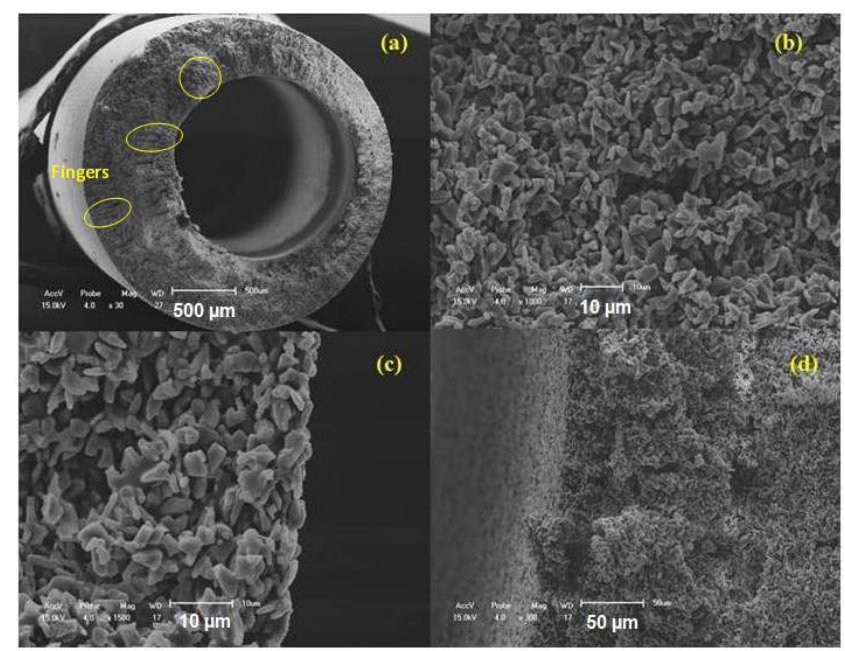

Figure 4: SEM images of the hollow fiber membrane sintered at $1450{ }^{\circ} \mathrm{C}$ at different magnifications.

The SEM image shown in Fig. 5a illustrates the surface near the outer part of the hollow fiber membrane sintered at $1500{ }^{\circ} \mathrm{C}$. As the membrane sintered at $1450{ }^{\circ} \mathrm{C}$, it was 
possible to check the presence of 'fingers' on the all external surface of the fiber, justifying the high porosity of the hollow fiber membrane. In Fig. 5b, the presence of irregular and asymmetric grains from the formation of silicon carbide is observed. Also, the outermost part of the hollow fiber can work as a porous support layer and the inner part of the membrane as a selective layer, which can increase the flow rate of the permeate. In Fig. 5c, the shape of the grains with irregular and asymmetric morphology is observed. With sintering at $1500{ }^{\circ} \mathrm{C}$, a continuous phase was clearly present, formed from the $\mathrm{SiO}_{2}-\mathrm{Al}_{2} \mathrm{O}_{3}$ system. In Fig. 5d, the crosssection close to the inner surface of hollow fiber is verified showing a porous surface. The morphologies identified for the two sintering temperatures indicated that the membranes were porous with irregular and asymmetric morphology. The pores were interconnected and this difference in morphology was responsible for the selectivity of the membrane [38].

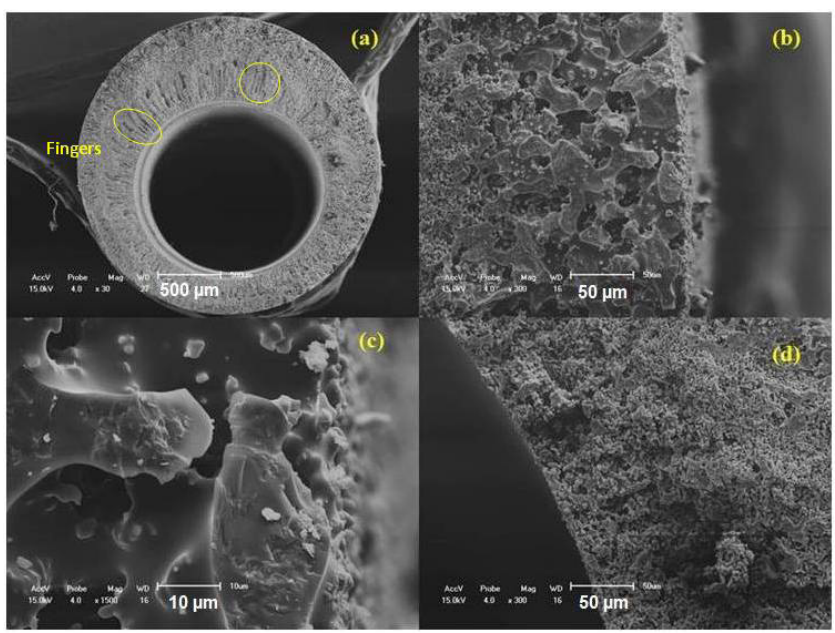

Figure 5: SEM images of the hollow fiber membrane sintered at $1500{ }^{\circ} \mathrm{C}$ at different magnifications.

The asymmetric morphology in the microstructure of the $\mathrm{SiC}$ hollow fiber membranes can be attributed to the rapid precipitation during the spinning process, which occurred in the core side which resulted in small channels and slow precipitation in the external side in the hollow fiber forming a spongy structure. Such morphology is typical for inorganic hollow fiber membranes prepared by the precipitationimmersion method $[10,39]$. The inner and outer diameters as well as the thickness of the sintered ceramic hollow fiber membranes are summarized in Table II. The increase in the sintering temperature from 1450 to $1500{ }^{\circ} \mathrm{C}$ led to a reduction in the dimensions of the hollow fiber membranes, which suggested higher densification at the higher sintering temperature.

Fig. 6 shows the AFM images of the membranes sintered at 1450 and $1500{ }^{\circ} \mathrm{C}$. The surfaces of the membranes presented distinct light and dark regions. The dark regions corresponded to areas of low height and the light regions to the highest areas. The concave parts of the images corresponded to the pores $[40,41]$. It was possible to visualize that with the increase in the sintering temperature,
Table II - Diameters and thickness of the silicon carbide hollow fiber membranes.

\begin{tabular}{cccc}
\hline $\begin{array}{c}\text { Sintering } \\
\text { temperature } \\
\left({ }^{\circ} \mathrm{C}\right)\end{array}$ & $\begin{array}{c}\text { Inner } \\
\text { diameter } \\
(\mathrm{mm})\end{array}$ & $\begin{array}{c}\text { Outer } \\
\text { diameter } \\
(\mathrm{mm})\end{array}$ & $\begin{array}{c}\text { Thickness } \\
(\mathrm{mm})\end{array}$ \\
\hline 1450 & $1.45 \pm 0.02$ & $2.41 \pm 0.14$ & $0.57 \pm 0.11$ \\
1500 & $1.43 \pm 0.03$ & $2.36 \pm 0.08$ & $0.54 \pm 0.13$ \\
\hline
\end{tabular}

there was an increase in the roughness on the membrane surface; this greater roughness can influence the filtration performance of the membrane since it is related to the pores of the membranes and can retain particles or impurities in membrane effluent treatments. In Fig. 6b, dark spots show this increase in roughness [40,42]. The average roughness was quantified and is shown in Table III.
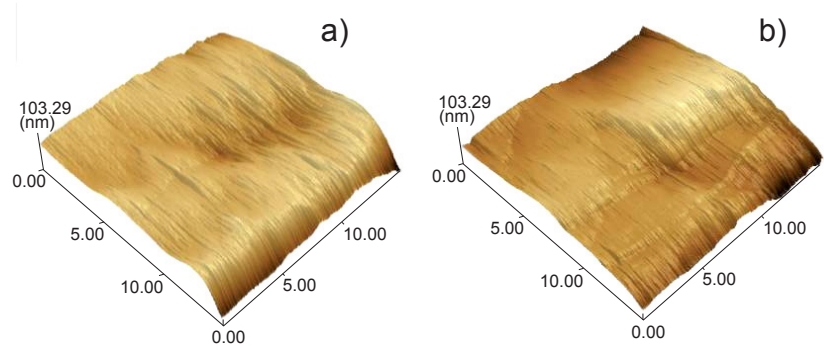

Figure 6: AFM images using dynamic mode $(15 \mathrm{x} 15 \mu \mathrm{m})$ of the surface of hollow fiber membrane sintered at $1450{ }^{\circ} \mathrm{C}$ (a) and $1500{ }^{\circ} \mathrm{C}(\mathrm{b})$.

Table III - Average roughness, average pore diameter, and porosity for $\mathrm{SiC}$ membranes sintered at 1450 and $1500{ }^{\circ} \mathrm{C}$.

\begin{tabular}{cccc}
\hline $\begin{array}{c}\text { Sintering } \\
\text { temperature } \\
\left({ }^{\circ} \mathrm{C}\right)\end{array}$ & $\begin{array}{c}\text { Roughness } \\
\mathrm{R}_{\mathrm{a}} \\
(\mathrm{nm})\end{array}$ & $\begin{array}{c}\text { Average pore } \\
\text { diameter } \\
(\mu \mathrm{m})\end{array}$ & $\begin{array}{c}\text { Porosity } \\
(\%)\end{array}$ \\
\hline 1450 & 15.84 & 4.50 & 57.38 \\
1500 & 22.67 & 6.35 & 52.53 \\
\hline
\end{tabular}

Fig. 7 shows the pore size distribution curves of the hollow fiber membranes sintered at 1450 and $1500{ }^{\circ} \mathrm{C}$. SiC membranes sintered at $1450{ }^{\circ} \mathrm{C}$ had an average pore size of $4.50 \mu \mathrm{m}$ and porosity of $57.38 \%$ (Table III). The rise in sintering temperature produced an increase in the average pore diameter of the membrane. According to Fukushima et al. [31], $\mathrm{SiC}$ with alumina showed a limited formation of $\mathrm{SiO}_{2}-\mathrm{Al}_{2} \mathrm{O}_{3}$ liquid phase during sintering from a thin $\mathrm{SiO}_{2}$ layer, which exists naturally on the surface of $\mathrm{SiC}$ particles, and the alumina additive. This liquid covering on the $\mathrm{SiC}$ particles may result in a limited mass transfer and the size of the grains increased with the increase of the sintering temperature [43]. The increase in sintering temperature caused a decrease in porosity and an increase in the size of the remaining pores, as can be seen in Fig. 5, resulting in average pore size of $6.35 \mu \mathrm{m}$ and porosity of $52.53 \%$.

The flexural strength of $\mathrm{SiC}$ hollow fiber membranes as 


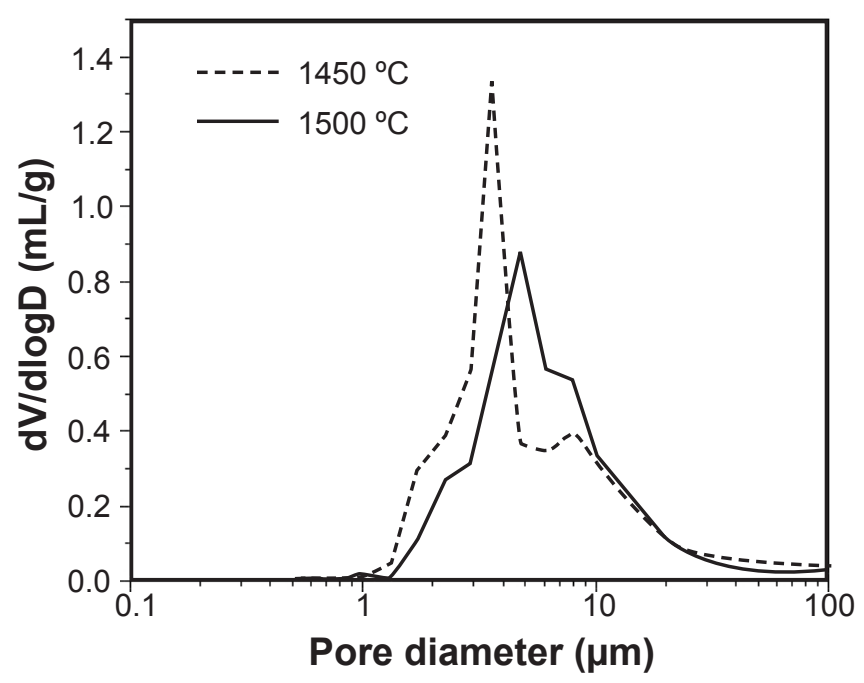

Figure 7: Volume-based pore size distribution curves by mercury intrusion for 1450 and $1500{ }^{\circ} \mathrm{C}$ sintered membranes.

a function of the sintering temperature is shown in Fig. 8. It was possible to observe that with the increase in the sintering temperature the membrane became stronger (83.1 MPa at $1450{ }^{\circ} \mathrm{C}$ and $98.1 \mathrm{MPa}$ at $1500^{\circ} \mathrm{C}$ ); this increase was related to the reduction of membrane porosity. When porous ceramics are subjected to mechanical testing, cracks of various orientations can growth, weakening the sample and causing eventual failure [44]. The pores act as stress concentrators, causing an increase in potential cracks and fractures [40, 44]. De Wit et al. [27] showed that for sintering temperatures above $1500{ }^{\circ} \mathrm{C}$ the mechanical resistance of the $\mathrm{SiC}$ membrane significantly reduces; this loss of strength is attributed to the removal of residual carbon at high processing temperatures, which makes it unfeasible for the production of hollow fiber membranes, which due to the thin walls require high strength to be subjected to high pressures during the treatment of effluents. Therefore, the elevation of the sintering temperature caused the grain growth and liquid phase formation, giving greater densification and increasing the mechanical strength. The membranes prepared with silicon carbide showed an excellent mechanical property, with the flexural strength above $80 \mathrm{MPa}$, and this was due to the $\mathrm{Si}-\mathrm{C}$ bonds (Fig. 8). These results were better than the ceramic membranes reported in the literature. Khalid et al. [40] prepared hollow silicon carbide fiber membranes and showed flexural strength of up to $45 \mathrm{MPa}$, for a sintering temperature of $1500^{\circ} \mathrm{C}$. Oliveira et al. [45] prepared hollow fiber alumina/quartzite residue membranes with a flexural strength between 20 and $82 \mathrm{MPa}$. Hubadillah et al. [46] prepared supports of kaolin hollow fiber membrane with strength values between 4 and $15 \mathrm{MPa}$ and $\mathrm{Li}$ et al. [47] produced hollow fiber membranes of pure alumina with flexural strength values ranging from $14.4 \pm 1.1$ to $38.1 \pm 3.5$ MPa sintered at 1500 and $1600^{\circ} \mathrm{C}$, respectively.

Fig. 9a presents the results of the permeated flow with distilled water at pressures of 100 and $200 \mathrm{kPa}$ for membranes sintered at 1450 and $1500{ }^{\circ} \mathrm{C}$. With a pressure of $100 \mathrm{kPa}$, the membrane presented permeated flow of

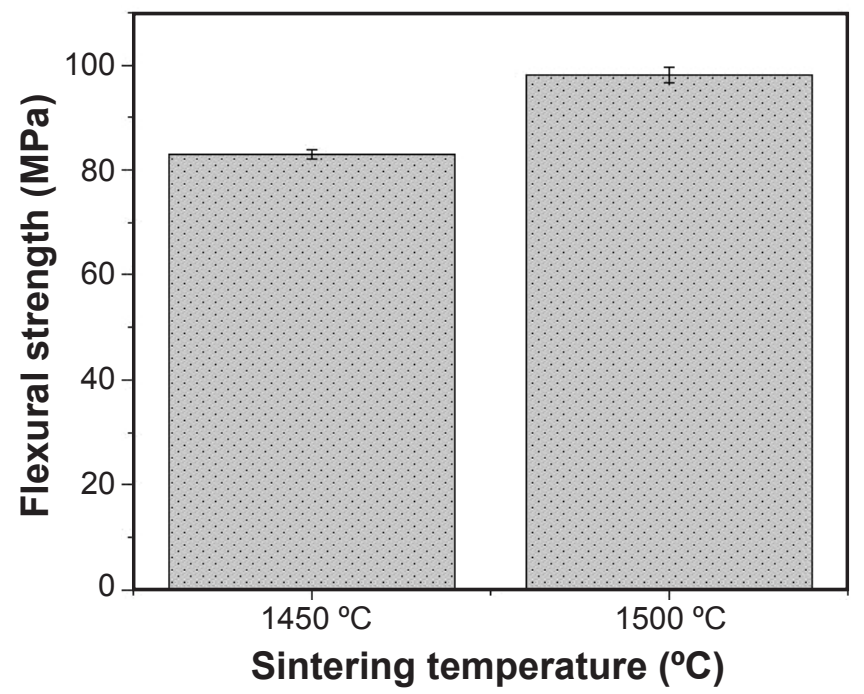

Figure 8: Flexural strength of $\mathrm{SiC}$ hollow fiber membranes as a function of sintering temperature.
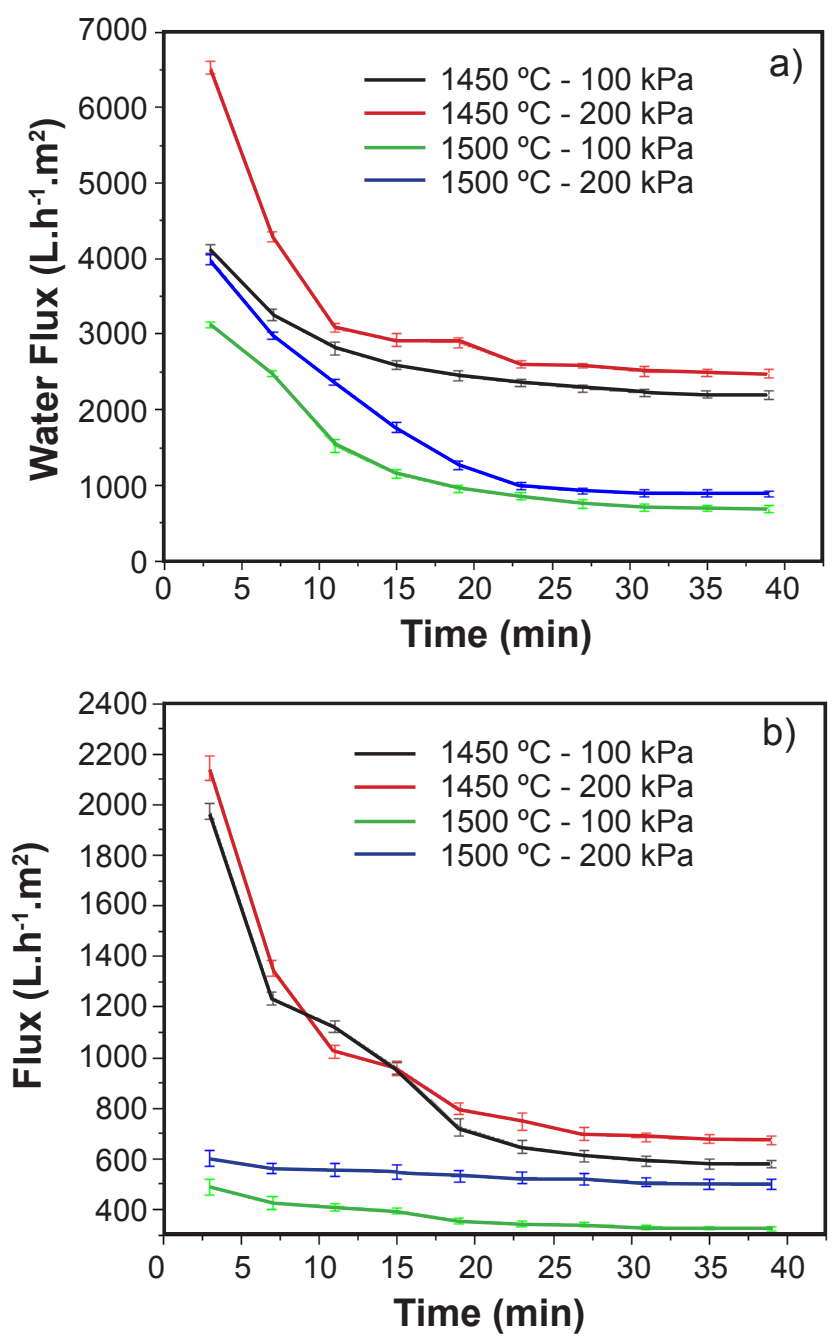

Figure 9: Permeate flow with distilled water (a) and textile effluent (b) for the $\mathrm{SiC}$ hollow fiber membrane sintered at 1450 and $1500{ }^{\circ} \mathrm{C}$.

approximately $4100 \mathrm{~L} \cdot \mathrm{h}^{-1} \cdot \mathrm{m}^{-2}$, followed by a decrease to $3250 \mathrm{~L} \cdot \mathrm{h}^{-1} \cdot \mathrm{m}^{-2}$. According to Elmaleh and Naceur [48] and Hubadillah et al. [49], the decrease of water permeated flow 
over time is due to the stability of water permeate through the membrane pores. The water molecule easily passes through the membrane pores. After some time, the pores are filled with water by the monolayer formation by adsorption of water molecules followed by the condensation of water molecules within the pores, and the flow of water through the membrane starts to become stable. The stability was reached at $2200 \mathrm{~L} \cdot \mathrm{h}^{-1} \cdot \mathrm{m}^{-2}$ after $35 \mathrm{~min}$ of the test. Increasing the pressure to $200 \mathrm{kPa}$, the permeated flow increased to $2470 \mathrm{~L}^{-\mathrm{h}^{-1}} . \mathrm{m}^{-2}$ after $35 \mathrm{~min}$ of the test. The water permeated flow of the sintered membrane at $1500{ }^{\circ} \mathrm{C}$ stabilized at $690 \mathrm{~L} \cdot \mathrm{h}^{-1} \cdot \mathrm{m}^{-2}$ after $35 \mathrm{~min}$ of test, a value that was lower than that of the membrane sintered at $1450{ }^{\circ} \mathrm{C}$. This lower flow value was associated with a smaller apparent porosity of this membrane (52\%). With the increase of the pressure to $200 \mathrm{kPa}$, a behavior similar to that of the membrane sintered at $1450{ }^{\circ} \mathrm{C}$ was observed, with permeated flow stabilizing at a higher value of $890 \mathrm{~L} \cdot \mathrm{h}^{-1} \cdot \mathrm{m}^{-2}$. Both membranes sintered at 1450 and $1500{ }^{\circ} \mathrm{C}$ presented high flow when compared to the values in the literature [50], which demonstrated the potential of this type of membrane for wastewater treatments.

Fig. $9 \mathrm{~b}$ presents the results of the permeated flow with textile effluent at pressures of 100 and $200 \mathrm{kPa}$ for membranes sintered at 1450 and $1500{ }^{\circ} \mathrm{C}$. With the pressure of $100 \mathrm{kPa}$, it was observed that the membrane sintered at $1450{ }^{\circ} \mathrm{C}$ presented permeate flow higher than $1970 \mathrm{~L} \cdot \mathrm{h}^{-1} \cdot \mathrm{m}^{-2}$ in the first minutes of the test. Then the permeated flow dropped and stabilized at $577 \mathrm{~L} \cdot \mathrm{h}^{-1} \cdot \mathrm{m}^{-2}$; this decrease with time was associated with the phenomenon of fouling, due to the accumulation of solutes on the surface of the membrane, causing clogging and decreasing the permeated flow [51]. With the increase of pressure to $200 \mathrm{kPa}$, the permeate flow stabilized at approximately $674 \mathrm{~L} \cdot \mathrm{h}^{-1} \cdot \mathrm{m}^{-2}$ after $35 \mathrm{~min}$ of the test. With the pressure of $100 \mathrm{kPa}$, the membrane sintered at $1500{ }^{\circ} \mathrm{C}$ presented an initial permeated flow of $500 \mathrm{~L} \cdot \mathrm{h}^{-1} \cdot \mathrm{m}^{-2}$ and stabilized at $327 \mathrm{~L} \cdot \mathrm{h}^{-1} \cdot \mathrm{m}^{-2}$ after $35 \mathrm{~min}$ of the test. The decrease in the permeated flow is typical of membrane processes due to the fouling phenomenon. Increasing the pressure to $200 \mathrm{kPa}$, the initial permeated flow increased to $600 \mathrm{~L} \cdot \mathrm{h}^{-1} \cdot \mathrm{m}^{-2}$ and stabilized at $500 \mathrm{~L} \cdot \mathrm{h}^{-1} \cdot \mathrm{m}^{-2}$ after $35 \mathrm{~min}$ of the test. The size and distribution of the pores influence the permeation rate. Molecules or particles can permeate or retain inside the membrane, clogging and locking the pores and consequently decreasing the permeate flow $[27,52]$.

Fig. 10 shows images of the textile effluent before and after treatment with the silicon carbide hollow fiber

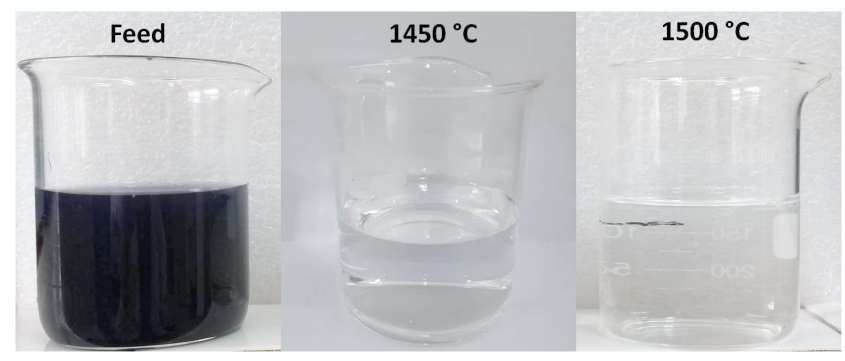

Figure 10: Images of textile effluent before and after treatment with $\mathrm{SiC}$ hollow fiber membrane sintered at 1450 and $1500^{\circ} \mathrm{C}$.

Table IV - Turbidity and color of the textile effluent before and after SiC hollow fiber membrane treatment.

\begin{tabular}{cccccc}
\hline Parameter & $\begin{array}{c}\text { Feed concentration, } \\
10000 \mathrm{ppm}\end{array}$ & $\begin{array}{c}1450{ }^{\circ} \mathrm{C}, \\
100 \mathrm{kPa}\end{array}$ & $\begin{array}{c}1450{ }^{\circ} \mathrm{C}, \\
200 \mathrm{kPa}\end{array}$ & $\begin{array}{c}1500{ }^{\circ} \mathrm{C}, \\
100 \mathrm{kPa}\end{array}$ & $\begin{array}{c}1500{ }^{\circ} \mathrm{C}, \\
200 \mathrm{kPa}\end{array}$ \\
\hline Turbidity (TU) & 409.0 & 2.6 & 6.6 & 1.0 & 2.1 \\
Color (MG Pt-Co/L) & 197.0 & 3.0 & 7.0 & 0 & 2.0 \\
\hline
\end{tabular}

Table V - Comparison of ceramic hollow fiber membranes prepared from different materials and with different applications reported in the literature.

\begin{tabular}{ccccccc}
\hline $\begin{array}{c}\text { Membrane } \\
\text { material }\end{array}$ & $\begin{array}{c}\text { Sintering } \\
\text { temperature } \\
\left({ }^{\circ} \mathrm{C}\right)\end{array}$ & $\begin{array}{c}\text { Flexural } \\
\text { strength } \\
(\mathrm{MPa})\end{array}$ & $\begin{array}{c}\text { Water } \\
\text { permeability } \\
\left(\mathrm{L} \cdot \mathrm{h}^{-1} \cdot \mathrm{m}^{-2}\right)\end{array}$ & $\begin{array}{c}\text { Flux } \\
\left(\mathrm{L} \cdot \mathrm{h}^{-1} \cdot \mathrm{m}^{-2}\right)\end{array}$ & $\begin{array}{c}\text { Selectivity } \\
(\%)\end{array}$ & Ref. \\
\hline Silicon carbide & 1000 & 36 & 500 & - & - & {$[27]$} \\
Alumina & 1250 & 51.3 & 12.58 & - & - & {$[53]$} \\
Alumina & 1500 & 89.8 & 18.72 & - & - & {$[54]$} \\
Silicon nitride & 1700 & 290 & 600 & - & - & {$[55]$} \\
Silicon nitride & 1700 & - & - & $200-800$ & $99-100$ & {$[43]$} \\
NaA/ $\boldsymbol{\gamma}$-alumina & 700 & 1.3 & 450 & 150 & 97.8 & {$[56]$} \\
Kaolin & 1300 & 13 & - & $20.5-23$ & $94-96$ & {$[46]$} \\
Silicon carbide & 1500 & 98.1 & 890 & 499 & $96-99$ & This study \\
Silicon carbide & 1450 & 83.1 & 2470 & 674 & $98.9-100$ & This study \\
\hline
\end{tabular}


membrane sintered at $1500{ }^{\circ} \mathrm{C}$. For the membranes sintered at $1500{ }^{\circ} \mathrm{C}$, at $100 \mathrm{kPa}$ of pressure, the turbidity and color values reached almost zero (Table IV). For the membranes sintered at $1450{ }^{\circ} \mathrm{C}$, at $100 \mathrm{kPa}$ of pressure, the values of turbidity and color increased in relation to the membranes sintered at $1500{ }^{\circ} \mathrm{C}$; however, considering the initial concentration of the effluent, there was also a significant rejection and high efficiency of the produced $\mathrm{SiC}$ hollow fiber membranes. The results indicated that the $\mathrm{SiC}$ hollow fiber membrane exhibited high mechanical resistance and water permeability, implying that this membrane has great potential for application in microfiltration processes. Taking textile effluent as an example (Table IV), the rejection and permeability values of the $\mathrm{SiC}$ hollow fiber were compared to values presented in the literature (Table V). The flux was higher than the reported results, while $>96 \%$ dye rejection was maintained. Thus, the $\mathrm{SiC}$ membrane prepared through phase inversion technique and low sintering temperature offers some advantages compared with the other membranes, such as high mechanical resistance, high permeated flow, and selectivity.

\section{CONCLUSIONS}

Silicon carbide hollow fiber membranes were successfully prepared by the precipitation-immersion technique. The membranes presented crystalline phases of silicon carbide and aluminum oxide when sintered at 1450 and $1500{ }^{\circ} \mathrm{C}$. The SEM images evidenced a porous and uniform surface for the membrane sintered at $1450{ }^{\circ} \mathrm{C}$ and a selective porous surface layer when sintered at $1500^{\circ} \mathrm{C}$. The increase of the sintering temperature increased the surface roughness. The membranes sintered at 1450 and $1500{ }^{\circ} \mathrm{C}$ presented high porosity (57\% and $52 \%$, respectively). The permeate flow measurements indicated the feasibility of the membranes for separation processes. The turbidity and color tests confirmed the viability of the use of the $\mathrm{SiC}$ hollow fiber membrane for the textile effluent treatment. The membranes of silicon carbide hollow fibers sintered at $1500{ }^{\circ} \mathrm{C}$ were more efficient than those sintered at $1450{ }^{\circ} \mathrm{C}$. The application of these membranes to microfiltration processes is feasible since the process ensures the high quality of the final effluent.

\section{ACKNOWLEDGMENTS}

The authors would like to acknowledge the CNPq and CAPES for financial support.

\section{REFERENCES}

[1] A.C. Habert, C.P. Borges, R. Nobrega, "Processos de separaçao com membranas", E-papers Ed., Rio Janeiro (2006).

[2] R.W. Baker, Membr. Technol. Appl. 3 (2004) 1.

[3] B.K. Nandi, R. Uppaluri, M.K. Purkait, Appl. Clay Sci. 42, 1-2 (2008) 102.

[4] E.C. Hammel, O.L.R. Ighodaro, O.I. Okoli, Ceram. Int.
40, 10 (2014) 15351.

[5] A. Huang, N. Wang, J. Caro, J. Membr. Sci. 389 (2012) 272.

[6] D.A. Fedosov, A.V. Smirnov, V.V. Shkirskiy, T. Voskoboynikov, I.I. Ivanova, J. Membr. Sci. 486 (2015) 189.

[7] L.P. Bessa, E.D.P. Ferreira, F.D.S. Magalhães, F.B. Ferreira, V.L. Cardoso, M.H.M. Reis, Ceram. Int. 45, 17 (2019) 23632.

[8] T. Wang, Y. Zhang, G. Li, H. Li, Front. Chem. Eng. China 3, 3 (2009) 265.

[9] A. Huang, B. Feng, J. Membr. Sci. 548 (2018) 59.

[10] X. Tan, S. Liu, K. Li, J. Membr. Sci. 188 (2001) 87.

[11] H. Fang, J.F. Gao, H.T. Wang, C.S. Chen, J. Membr. Sci. 403 (2012) 41.

[12] J.M. Benito, A. Conesa, M.A. Rodríguez, Bol. Soc. Esp. Ceram. V. 43 (2004) 829.

[13] H.P. Hsieh, Inorganic membranes for separation and reaction, Elsevier, Amsterdam (1996).

[14] L.G. Ceballos-Mendivil, R.E. Cabanillas-Lopez, J.C. Tanori-Cordova, R. Murrieta-Yescas, C.A. Perez-Rabago, H.I. Villafan-Vidales, C.A. Estrada, Sol. Energy 116 (2015) 238.

[15] L. Hozer, J.R. Lee, Y.M. Chiang, Mater. Sci. Eng. 195 (1995) 131.

[16] Y. Yang, W. Xu, F. Zhang, Z.X. Low, Z. Zhong, W. Xing, J. Membr. Sci. 541 (2017) 500.

[17] A. Gubernat, L. Stobierski, P. Łabaj, J. Eur. Ceram. Soc. 27 (2007) 781.

[18] J.H. She, T. Ohji, Mater. Chem. Phys. 80 (2003) 610.

[19] S. Ding, S. Zhu, Y. Zeng, D. Jiang, Ceram. Int. 32 (2006) 461.

[20] Y.C. Xu, X.Q. Cheng, J. Longo, L. Shao, J. Membr. Sci. 497 (2016) 77.

[21] M.J. Geerken, M.N.W. Groenendijk, R.G.H. Lammertink, M. Wessling, J. Membr. Sci. 310 (2008) 374.

[22] K.M.D. Medeiros, E.M. Araújo, H.D.L. Lira, D.D.F. Lima, C.A.P.D. Lima, Mater. Res. 20, 2 (2017) 308.

[23] M.H. Armoa, J.M. Jafelicci, Ciênc. Tecnol. 2 (2011) 80.

[24] C. Castel, E. Favre, J. Membr. Sci. 548 (2018) 345.

[25] S.S.L. Oliveira, R.S.B. Ferreira, B.A. Araújo, S.S.L. Oliveira, H.L. Lira, E.M. Araújo, Rev. Eletr. Mater. Proces. 11, 3 (2016) 164.

[26] N. Kamoun, W. Hajjeji, R. Abid, M.A. Rodriguez, F. Jamoussi, Cerâmica 66, 380 (2020) 386.

[27] P. De Wit, E.J. Kappert, T. Lohaus, M. Wessling, A. Nijmeijer, N.E. Benes, J. Membr. Sci. 475 (2015) 480.

[28] M. Dilaver, S.M. Hocaoğlu, G. Soydemir, M. Dursun, B. Keskinler, İ. Koyuncu, M. Ağtaş, J. Clean. Produc. 171 (2018) 220.

[29] P.K. Lin, D.S. Tsai, J. Am. Ceram. Soc. 80 (1997) 365. [30] M. Fukushima, Y. Zhou, H. Miyazaki, Y. Yoshizawa, K. Hirao, Y. Iwamoto, S. Yamazaki, T. Nagano, J. Am. Ceram. Soc. 89 (2006) 1523.

[31] M. Fukushima, Y. Zhou, Y.I. Yoshizawa, J. Membr. Sci. 339 (2009) 78.

[32] V.A. Izhevskyi, L.A. Genova, A.H.A Bressiani, J.C. Bressiani, Mater. Res. 3 (2000) 131. 
[33] N. Nikkam, M. Saleemi, E.B. Haghighi, M. Ghanbarpour, R. Khodabandeh, M. Muhammed, M.S. Toprak, Nano-Micro Lett. 6 (2014) 178.

[34] M.C. Fraga, S. Sanches, V.J. Pereira, J.G. Crespo, L. Yuan, J. Marcher, J. Benavente, J. Eur. Ceram. Soc. 370 (2017) 899.

[35] S.R.F. Vlach, Rev. Inst. Geociênc. USP 1 (2002) 1.

[36] W. Rui, C. Zhang, C. Cai, X. Gu, J. Membr. Sci. 489 (2015) 90 .

[37] G. Chen, H. Qi, W. Xing, N. Xu, J. Membr. Sci. 318 (2008) 38.

[38] J. Nikkola, J. Sievänen, M. Raulio, J. Wei, J. Vuorinen, C.Y. Tang, J. Membr. Sci. 450 (2014) 174.

[39] B. Kingsbury, K. Benjamin, J. Membr. Sci. 328 (2009) 134.

[40] A. Khalid, A. Abdel-Karim, M.A. Atieh, S. Javed, G. Mckay, Sep. Purif. Technol. 190 (2018) 165.

[41] W. Deng, X. Yu, M. Sahimi, T.T. Tsotsis, J. Membr. Sci. 451 (2014) 192.

[42] H. Cai, H. Fan, L. Zhao, H. Hong, L. Shen, Y. He, J. Chen, J. Colloid Interface Sci. 465 (2016) 33.

[43] J.W. Zhang, H. Fang, J.W. Wang, L.Y. Hao, X. Xu, C.S. Chen, J. Membr. Sci. 450 (2014) 197.

[44] F. Vales, R. Rezakhanlou, C. Olagnon, J. Mater. Sci. 341 (1999) 4081.

[45] S.S.L. Oliveira, S.S.L. Oliveira, R.D.S.B. Ferreira,
H.D.L. Lira, L.N.D.L. Santana, E.M. Araújo, Mater. Res. 22 (2019) 1.

[46] S.K. Hubadillah, M.H.D. Othman, A.F. Ismail, M.A. Rahman, J. Jaafar, Sep. Purif. Technol. 241 (2019) 31.

[47] L. Li, M. Chen, Y. Dong, X. Dong, S. Cerneaux, S. Hampshire, J. Liu, J. Eur. Ceram. Soc. 36 (2016) 2057.

[48] S. Elmaleh, W. Naceur, J. Membr. Sci. 66 (1992) 227. [49] S.K. Hubadillah, M.H.D. Othman, A.F. Ismail, M.A. Rahman, J. Jaafar, Y. Iwamoto, M.Z.M. Yusop, Ceram. Int. 44 (2018) 10498.

[50] S.H. Paiman, M.A. Rahman, M.H.D. Othman, A.F. Ismail, J. Jaafar, A.A. Aziz, Ceram. Int. 41, 10 (2015) 12543. [51] M.P. Magalhães, F.D.S. Gomes, R.C.D. Modesta, V.M.D. Matta, L.M.C. Cabral, Food Sci. Technol. 25 (2005) 72.

[52] T.T. Silva, R.C. Della Modesta, P.E. das Mercês, V.M. da Matta, L.M.C. Cabral, Pesq. Agropec. Bras. 40, 4 (2005) 419.

[53] N.M. Terra, G.S. Madrona, F.B. Ferreira, V.L. Cardoso, M.H.M. Reis, Food Bioproc. Tech. 12, 1 (2019) 27.

[54] M. Lee, B. Wang, K. Li, J. Membr. Sci. 503 (2016) 48. [55] J.W. Zhang, H. Fang, L.Y. Hao, X. Xu, C.S. Chen, Mater. Lett. 68 (2012) 457.

[56] T.L.A. Barbosa, F.M.N. Silva, A.S. Barbosa, E.G. Lima, M.G.F. Rodrigues, Cerâmica 66, 378 (2020) 137.

(Rec. 14/09/2020, Rev. 26/10/2020, 12/12/2020, Ac. $16 / 12 / 2020)$ 